\title{
Solvability of mental health care in the Family Health Strategy: social representation of professionals and users
}

\author{
RESOLUBILIDADE DO CUIDADO EM SAÚDE MENTAL NA ESTRATÉGIA SAÚDE DA \\ FAMÍLIA: REPRESENTAÇÃO SOCIAL DE PROFISSIONAIS E USUÁRIOS
}

\author{
RESOLUBILIDAD DEL CUIDADO EN SALUD MENTAL EN LA ESTRATEGIA SALUD DE LA \\ FAMILIA: REPRESENTACIÓN SOCIAL DE PROFESIONALES Y USUARIOS
}

\section{Maria Salete Bessa Jorge ${ }^{1}$, Mardênia Gomes Ferreira Vasconcelos ${ }^{2}$, Euton Freitas de Castro Junior ${ }^{3}$, Levi Alves Barreto ${ }^{3}$, Lianna Ramalho de Sena Rosa ${ }^{4}$, Leilson Lira de Lima ${ }^{5}$}

\begin{abstract}
Objective: To aprehend the social representations about the solvability in mental health care with users of the Family Health Strategy and professionals of family health teams and of the Center for Psychosocial Care. Method: A qualitative study using semi-structured interviews for data collection, and the Alceste software for analysis. This software uses the Hierarchical Descending Classification based on the examination of lexical roots, considering the words as units and providing context in the corpus. Results: The representations emerge in two opposing poles: the users require satisfaction with care and the professionals realize the need for improvement of health actions. Although the matricial support in mental health and the home visits are developed, the barriers related to investment in health, continuing education and organization of care persist. Conclusion: The different representations enable improvements in customer service, solvability of care and aggregate knowledge and practices in the expanded perspective of health needs in the family, social and therapeutic context.
\end{abstract}

\section{DESCRIPTORS}

Integrality in health

Family Health Strategy

Mental health

Mental Health Services

Psychiatric nursing

\section{RESUMO}

Objetivo: Apreender as representações sociais sobre resolubilidade do cuidado em saúde mental na Estratégia Saúde da Família de usuários e profissionais de equipes de saúde da família e Centro de Atenção Psicossocial. Método: Estudo qualitativo com uso de entrevista semiestruturada para coleta das informações e o software Alceste para análise. Este software usa a Classificação Hierárquica Descendente com base no exame das raízes lexicais, considerando a palavra como unidade e oferece contextualização no corpus. Resultados: As representações emergem em dois polos antagônicos: usuários referem satisfação com o atendimento e profissionais percebem a necessidade de melhoria das ações de saúde. São desenvolvidos matriciamento em saúde mental e visita domiciliar, mas persistem entraves relacionados ao investimento em saúde, educação permanente e organização da assistência. Conclusão: As diferentes representações ensejam melhoria do atendimento, resolubilidade do cuidado e congregam saberes e práticas na perspectiva ampliada das necessidades de saúde no contexto familiar, social e terapêutico.

\section{DESCRITORES}

Integralidade em saúde

Estratégia Saúde da Família

Saúde mental

Serviços de Saúde Mental

Enfermagem psiquiátrica.

\section{RESUMEN}

Objetivo: Asimilar las representaciones sociales acerca de la resolubilidad del cuidado en salud mental en la Estrategia Salud de la Familia de usuarios y profesionales de equipos de salud de la familia y Centro de Atención Psicosocial. Método: Estudio cualitativo con empleo de entrevista semiestructurada para recolección de las informaciones y el software Alceste para análisis. Este software utiliza la Clasificación Jerárquica Descendente con base en el examen de las raíces lexicales, considerando la palabra como unidad y proporciona la contextualización en el corpus. Resultados: Las representaciones emergen en dos polos antagónicos: usuarios relatan satisfacción con la atención y profesionales advierten la necesidad de mejoría de las acciones de salud. Se desarrollan el matriciamiento en salud mental y la visita domiciliaria, pero persisten los óbices relacionados con la inversión en salud, la educación permanente y la organización de la asistencia. Conclusión: Las diferentes representaciones proporcionan mejoría de la atención, resolubilidad del cuidado y congregan saberes y prácticas en la perspectiva ampliada de las necesidades de salud en el contexto familiar, social y terapéutico.

\section{DESCRIPTORES \\ Integralidad en salud \\ Estrategia de Salud Familiar \\ Salud mental \\ Servicios de Salud Mental \\ Enfermería psiquiátrica.}

1 Professor, Universidade Estadual do Ceará, Fortaleza, CE, Brazil. 2 Substitute Professor, Nursing Undergraduate Course, Universidade Estadual do Ceará, Fortaleza, CE, Brazil. ${ }^{3}$ Medicine Undergraduate Student, Universidade Estadual do Ceará, Fortaleza, CE, Brazil. ${ }^{4}$ MSc in Public Health, Universidade Estadual do Ceará, Fortaleza, CE, Brazil. ${ }^{5}$ Substitute Professor, Medicine Undergraduate Course, Universidade Estadual do Ceará, Fortaleza, CE, Brazil. 


\section{INTRODUCTION}

The search for solvability in mental health care requires the organization of a network of services and deepening of the subjective relationships among professionals, users and families. The key points in this search are to ensure access to quality services, in addition to establishing relationships that produce bonds and user embracement. Indeed, a resolute service should be able to address and solve the problem up to the limit of its performance ${ }^{(1)}$.

Solvability is considered a dependent variable when analyzing the health care system in elements like access, user embracement, the bonding and accountability, and at the same time, an independent variable, with respect to services and networks of care. The ability to address and solve problems is associated with the implementation of services and technologies; the reorganization of work processes; the formation of networks; the technological densification to optimize resources; the coordination and complementarity of services and networks of care; and the conformation of the production lines of care ${ }^{(2)}$.

Therefore, the desired solvability in mental health care may be the result of establishing a care network coordinated among the levels of complexity of the Unified Health System (SUS - Sistema Único de Saúde), based on the health needs of each system user, on the investments in subjective relationships between professionals/users/ families in care production, and on devices that promote access and continuity of care in the territory, as in the case of the matricial mental health.

Based on the foregoing, emerged the objective of delimitating the concept of solvability with origin in the theoretical dialogue with several authors ${ }^{(2-8)}$, by analyzing it based on elements such as access, service network and the production of comprehensive care. This delineation will assist in the knowledge of mental health services in primary care that are put into practice in coordination with the Family Health Strategy (FHS), from the problematization of the solvability of practices.

The problematization of practices and their solvability based on the representations of social agents demarcate a fertile ground for formulating knowledge in the mental health field, guiding the actions and the production of comprehensive care. Thus, the study aimed to apprehend the social representations about solvability in mental health care in the FHS among professionals from this team, of the Center for Psychosocial Care (CAPS - Centro de Atenção Psicossocial), and the service users..

\section{METHOD}

This is a qualitative study that integrates a wider research project called Production of care in the Family Health Strategy and its interface with mental health: challenges in search of solvability, funded by the Conselho Nacional de Desenvolvimento Científico e Tecnológico (CNPq) and approved by the Ethics Committee on Research with Human Beings of the Universidade Estadual do Ceará under protocol number 08573214-1.

The locus of the investigation were two family health centers and two Centers for Psychosocial Care (CAPS) in the city of Fortaleza, capital of the state of Ceará. It was a non-probabilistic intentional and accidental sample consisting of 44 subjects, of which 20 were professionals of the Family Health staff, 10 were professionals from the CAPS (including physicians, nurses, dentists, psychologists, social workers, pharmacists, nurse technicians and community health agents), and 14 were service users. The inclusion criteria were the professionals who participated in the meetings and discussions of the matricial mental health, and the patients seen in this care modality, considering the consent of the subjects for participating in the study. A semistructured interview was used to obtain the information.

Then, a database was organized, following the operational stages proposed in another study ${ }^{(9)}$. The interviews were transcribed verbatim and the formatting of the corpus was held in a single file. The procedures for data analysis were supported by the ALCESTE software (Lexical Analysis by Context of a set of text segments) in its version 4.5, which was developed in France ${ }^{(10)}$. It is noteworthy that the software analysis involves operational steps, including reading the text and calculation of dictionaries; calculation of data matrices and classification of elementary context units (ECU); description of the ECU classes; and additional calculations ${ }^{(9)}$.

The Alceste is a technique for analyzing textual data that allows exploring the structure and organization of the discourse of social agents, and also the access to the relations between lexical universes that would possibly be difficult to identify using traditional content analysis ${ }^{(11)}$.

Aiming to preserve the anonymity of the participants, the speech excerpts that emerged from Alceste structured interviews were identified as follows: Professionals, textual summaries from the program analysis and related to the speeches of professionals from the CAPS and FHS, and Users, textual summaries from the program analysis and related to the speeches of users.

\section{RESULTS}

The results formed by the corpus of 44 Initial Context Units (ICU) that represent the unit (interviews) with origin where the Alceste software made the initial fragmentation, indicated a division of that corpus in 740 Elementary Context Units (UCE) corresponding to $69 \%$ of the total, containing 3,184 different words, averaging ten occurrences per word. Following the criteria proposed by the
Solvability of mental health care in the family health strategy: social representation of professionals and users Jorge MSB, Vasconcelos MGF, Junior EFC, Barreto LA, Rosa LRS, Lima LL 
program, the terms with frequency lower than three were disregarded in the analysis of corpus, regarding the criteria established for calculating the $\chi 2$ (words with frequency greater than three, consequently, with $\chi 2$ from 3.84 is significant with a degree of freedom).

Thus, after the description of the frequency and percentage of words, came the Hierarchical Descending Classification (HDC), which represents the degree of similarity and proximity of the corpus contents. This was defined as the solvability of mental health care in the Family Health Strategy and was the subject of partitions distributed into six classes, formed with at least $21 \mathrm{ECU}$ and originating the subcorpus. For preparation of the classes and subcorpus, words with $\chi 2$ $\leq 134$ and $\chi 2 \geq 12$ with $\mathrm{gl}=1$ were taken as references.

It is possible to realize the division of discursive material in two subcorpus, showing the relation between classes. The first subcorpus was subdivided by grouping the classes 1, 2 and 3, which have a higher relation, or proximity, and then the classes 4 and 5, which have specific meanings and ideas to justify its grouping in a similar category. The second subcorpus merged the class 6, revealing a sense of opposition between the class 6 and the previous classes, and little or no relationship between the three first classes and the last three classes. The figure also describes the title of each class, followed by the number of ECU that compose it, its description, as well as the descriptive variables and words of greatest association with the referred class, taking into consideration the coefficient found in the $\chi 2$ test of association.

It is noteworthy that the social representations of the mental health solvability in the FHS were structured into three representational fields, namely: the first was composed of the classes 1, 2 and 3, which correspond to Improvements in health care: humanization, training in mental health and home care with predominance of representations of the FHS professionals. With respect to the second field, it was structured by classes 4 and 5 , highlighting the Continuity of care initiatives in mental health: multidisciplinary team and guarantee of access to services, organized around the representational contents of CAPS professionals, more specifically. The third field was named Assistance: waiting, quality and satisfaction, structured by the class 6 , which can be represented by service users. All fields and classes will be discussed below, considering the ECU found in each class.

\section{Improvements in health care: humanization, training in mental health and home care}

\section{Class 1: Improvements in health care}

The number of ECU structuring the Class 1 (107 ECU with 41 word radicals, which means $21 \%$ of the total ECU), shows that this is the class of largest explanatory power. Regarding the descriptive variables, the Class 1 can be characterized as consisting of health professionals in most cases, including nursing assistants and dental assistants.
The words of greater association of this Class are related to the macro-political and micro-political context of transformation of the health system, aimed at humanization of care, according to the elementary context units that most characterize the Class 1 and described below:

(...) then, there must be an improvement in the SUS to solve these problems (...). The city hall had fundings to pass. (...) there should be more investment in the SUS and always look for the managers, invest more in areas that need more monitoring. (...) we must seek to be better, to be able to meet the demand of higher quality. (...) not be working all the time like a machine. (...) I will treat that patient in the best possible way with the professional ethics with humanization (Professionals).

\section{Class 2: Matricial mental health}

This class was composed of 91 ECU with 43 word radicals, corresponding to $18 \%$ of the ECU, considering the interval between $\chi 2=116$ (matriciamer) and $\chi 2=12$ (ment). The descriptive variables that most contributed to this class were composed of health professionals, especially the category of nurses.

The central notion of this class of social representations about the solvability of mental health care in the FHS is the matricial action in the approach and training of teams. This can be noticed with origin in the elementary context units that most characterize the Class 2 in the semantic contents below:

(...) we had a training in the CAPS with the NASF team [Núcleos de Apoio à Saúde da Família/Centers to Support Family Health], the doctors, nurses and assistants, all the FHS team to treat these cases, which are not few, many are mild, moderate disorders. (...) the most severe are in the CAPS. We wont make more referrals to the CAPS because that whole team is solving the problem of the patient. We debate, discuss (...) for us, the professional is a reference. (...) the patients like, they dont need to go to the CAPS. (...) they ask to join the matricial. (...) but for patients it's better than for us, professionals (Professionals).

\section{Class 3: Home visit}

This class obtained 101 ECU and 43 word radicals, accounting for $20 \%$ of the ECU. It was composed with radicals and words in the interval of $\chi 2=114$ (visit) and $\chi 2=17$ (conhec). With respect to the descriptive variables, this was typically composed of health professionals who work in the FHS, the community health agents (CHA).

The predominance of contents related to work at home with the bedridden and caregivers is also noticed. Such information indicates that the care closer to users and their families contributes to the social representation about the solvability of care, as can be seen in the most characteristic ECU of this class: 
(...) in home visits, we offer guidance. (...) we make the visit with each nurse and offer guidance on home care, in some visits the physiotherapist comes along, the elderly is bedridden there. (...) then, the physiotherapist will teach the caregiver about the exercises that are possible to make. (...) because our work is educational, it is informative, then people know that in the day, for example, on Wednesday there will be childcare, so they already bring the children (...), and very rarely we find some resistance (Professionals).

\section{Continuity of care initiatives in mental health: multidisciplinary team and guarantee of access to services}

\section{Class 4: Therapeutic group and the continuity of care}

The number of ECU that structured this class was 81 and 43 word radicals, or $16 \%$ of the ECU. It was composed with radicals and words in the interval of $\chi 2=81$ (group) and $\chi 2$ $=16$ (inici). The descriptive variables that most contributed to this class were health professionals, in particular the pharmacists category of the Center for Psychosocial Care.

It is clear, therefore, that the solvability is related to the diversity of care actions, whether in therapeutic group or in individual modalities of care by the multidisciplinary team, as the ECU that most characterize the Class 4, and described below:

(...) we have encouraged the existence of groups from the units, with professionals of local teams in charge in the therapeutic context. (...) the continuity of care actions will depend a lot, just after the initial evaluation, patients will have their own care modality. We have intensive, semiintensive and non-intensive patients. (...) within the service is offered outpatient care, social work, nursing care, psychology, psychiatry, occupational therapy. We have thought of larger strategies, too. (...) to start an open group next year, in which women and men with disorders would work too (Professionals).

\section{Class 5: Access and organization of the system}

This class accounted for $61 \mathrm{ECU}$ and 41 word radicals, or $12 \%$ of ECU. It was composed of radicals and words in the interval of $\chi 2=134$ (acess) and $\chi 2=21$ (atenc). In face of such classifications, we observe that this class can be considered as the one of lowest explanatory power among the surveyed participants. But taking the descriptive variables into account, we can characterize the class as consisting primarily of health professionals, highlighting the social workers category of the CAPS.

We observed the predominance of contents that relate to changes in the services organization, aimed at ensuring access and network coordination, identifying the matricial as the support in mental health care in primary care, which are requirements for the solvability of assistance, and shown in the most typical ECUs of this class:
(...) our county is divided into six regions, but at the same time, we try to respect this division of regional boundary in the sense that the actual access, either by users for using the service, as in the case of visits, with easy access for us getting there. (...) Hierarchization, regionalization are used in organizing the operation of services, and not just to make the system bureaucratic and stiff. (...) and then, the matricial support has been crucial and I dont mean only in relation to the reorganization of the service flow, I also mean in relation to our patients who have been historically relegated to have basic care. (...) showing the family that this person has the right of transit and access to services that are available in the community. (...) I always put it like this. (...) look at that little room in the back, it doesnt go only to the kitchen, sometimes after the kitchen there is a small room back there, someone who has a mental disorder. (Professionals).

\section{Assistance: waiting, quality and satisfaction}

\section{Class 6: Assistance: waiting, quality and satisfaction}

This class was structured with $66 \mathrm{ECU}$, representing $13 \%$ of the total. It was composed of words and radicals in the interval of $\chi 2=118$ (atendid) and $\chi 2=23$ (diss). In relation to descriptive variables, the Class 6 is formed by health care services users in the FHS and CAPS.

The central idea of this class is organized around the satisfaction with the service provided. Service users describe the service of receiving medication as of quality, according to the semantic content below:

\begin{abstract}
(...) the service is good. The doctor always asks me if I have any questions, if I have, I ask. (...) health professionals do everything right. They ask things, and examine and everything. (...) whenever they cannot handle it all here, they send us somewhere else and we are attended. (...) workers are nice here, treat me well and all. I like, but sometimes it takes long. (...) what I dont like is the waiting. (...) like today, Ive been waiting here for two hours, but still, I know I will be seen and go home with the medicine (Users).
\end{abstract}

\section{DISCUSSION}

From the results presented, it can be stated that the mental health care in the FHS combines representations at macro and micro-political level. At the macro-political level, there is the need for greater investment in public health policies, staff training and system organization. At the micro-political level, the representations focus on the satisfaction with care, especially regarding the access to medicines, the relationships established between the staff and users, and the service offer.

Although the principles of the Psychiatric Reform, together with the legal and operational structure of the FHS are fundamental in the reorientation of services and care practices in mental health to integral and effective
Solvability of mental health care in the family health strategy: social representation of professionals and users Jorge MSB, Vasconcelos MGF, Junior EFC, Barreto LA, Rosa LRS, Lima LL 
care $^{(12-13)}$, there are still many challenges to consolidate and expand a care network of community and territorial base that promotes social reintegration and citizenship. Among such challenges, is increasing the resources of the SUS annual budget for mental health ${ }^{(14)}$, as well as enabling and encouraging investment in the mental health services in primary care.

It is noteworthy that the necessary humanization of the public health system and the capacity of providing mental health care permeate the deconstruction of crystallized processes of management, funding and working in health services ${ }^{(15)}$. In the absence of organization, prevail unnecessary referrals and the consequent waiting list, shortage of professionals in the services and the low coverage of the FHS teams ${ }^{(16)}$.

Another issue in the social representations of participants are the human resources for the services. They have proven insufficient for the training needs of workers in the mental health network, including the FHS. Most of these professionals work under the sign of the Psychiatric Reform and graduated at schools that in general still teach the doctor-centered and biologicist model of attention. Therefore, there is a pressing need to propose and implement projects of training or qualification on a large scale ${ }^{(14)}$.

Still at macro-political level, the CAPS professionals associate the guarantee of access through hierarchization and regionalization of services with the solvability of mental health care. They report that the provision of services occurs in an organized way, by level of technological complexity, which also favors the guarantee of access to health services for people with mental disorders.

However, studies have shown the difficulties of the mental health services network. Although the primary care is advocated as the gateway, with the participation of mental health professionals in primary health care, the access to these services and their coordination with other levels of mental health care is still below that recommended by the IV National Conference of Mental Health, in view of the completeness and solvability of actions ${ }^{(17)}$.

The quality and continuity of care depend on the coordination between primary care and other mental health services at different levels of complexity, from the Center for Health, passing by the CAPS and involving referral hospitals when necessary, helping to improve the care provided and the expansion of the population access to services ${ }^{(18)}$.

At micro-political level, the solvability of mental health care is related to the satisfaction with the care received. This satisfaction seems combined with the access to pharmacological therapy and necessary referrals, and with the relations established between users and health workers.

Indeed, the representations describe the relationship between the users with services and the health workers.
The solvability of care, therefore, is reported from the perspective of those who are being assisted by the service, and it is possible to aprehend the positive meaning attributed to the interpersonal relationships and access to medicines, present in the management of the healthdisease-care.

Thus, users resignify the value of drug therapy in the care received. They acknowledge the importance of medicines in the therapeutic practice, but recognize the necessary coexistence of other therapeutic mechanisms in the process, such as listening and user embracement: users favor consultations focused on the prescriptive act on the one hand, but on the other, recognize the importance of listening ${ }^{(19)}$.

It is important to emphasize that the listening and user embracement as soft technologies are key instruments for the solvability of mental health care, because they facilitate the permanence of users in the service and therefore, in the treatment. The use of light technologies allows thinking about health care in the wholeness of the subject, the environment and relationships, because care is the construct of social, economic and family aspects, as well as biological, psychological and cultural ${ }^{(4,20)}$.

The matricial support, the home visits and therapeutic groups appear as present activities in the services that favor the solvability of mental health care. Such activities mobilize the team to an intersubjective approach, noting issues and conditions of the psychosocial dimension, both in socioeconomic aspects, as in the clinical condition, facilitating the access and making effective the resolution of complaints and needs ${ }^{(3)}$.

The matricial support, for example, improves communication among teams with the exchange of experiences, which favors the recognition of each service activities and the access to territorial care. From it, the objective is to provide a better understanding of mental health for primary care professionals, enabling them to act as facilitators in the therapeutic process, share territorial information, clinical and procedures demands, as well as broaden their resolving potential towards the clinical cases of mental health ${ }^{(3,21)}$.

In addition, there is the diversity of therapeutic actions on mental health in the FHS. They are expressed in the daily work of the teams that involves the effective participation of community health agents ( $\mathrm{CHA})$ in care, since they are closer to the territory. The highlights among the actions taken are the home visits and the formation of therapeutic groups.

Because of the closeness to the environment in which individuals live, the home visit is a strategy that allows access to health services, coordinates the health promotion and disease prevention and enables greater knowledge of the everyday life in the community, gathering valuable information about the factors that determine the quality 
of life and health ${ }^{(22)}$. Thus, this activity contributes to decrease the demand for specialized services of mental health and reduce the hospitalization rates ${ }^{(23)}$.

Furthermore, therapeutic groups that occur in the everyday life of care reveal common attitudes of each health professional, and are perceived by users and families as something positive for the improvement of life. In an innovative process, the clinical approaches become horizontal in the uniqueness of each user, recognizing their existential, subjective and especially social place ${ }^{(3)}$.

\section{CONCLUSION}

For professionals, either from the FHS or CAPS, the representation of the solvability of care differ from the representation of users, because the first realize the need for improvements in the overall context of the Unified Health System to meet the quality needs of users. However, the users report to be satisfied with the service received, despite the delays. These positions are influenced by information, knowledge and

\section{REFERENCES}

1. Brasil. Ministério da Saúde; Secretaria Nacional de Assistência à Saúde. ABC do SUS: doutrinas e princípios. Brasília; 1991.

2. Santos RC. Saúde todo dia: uma construção coletiva. São Paulo: Hucitec; 2006.

3. Pinto AGA, Jorge MSB, Vasconcelos MGF, Sampaio JJC, Lima JP, Bastos VC, et al. Apoio matricial como dispositivo do cuidado em saúde mental na atenção primária: olhares múltiplos e dispositivos para a resolubilidade. Ciênc Saúde Coletiva. 2012;17(3):653-60.

4. Jorge MSB, Pinto DM, Quinderé PHD, Pinto AGA, Sousa FSP, Cavalcanto CM. Promoção da Saúde Mental: tecnologias do cuidado: vínculo, acolhimento, co-responsabilização e autonomia. Ciênc Saúde Coletiva. 2011;16(7):3051-60.

5. Arona EC. Implantação do matriciamento nos serviços de saúde de Capivari. Saúde Soc. 2009;18(1):26-36.

6. Guimarães JMX. Satisfação dos trabalhadores de saúde mental: o caso dos centros de atenção psicossocial de Fortaleza Ceará. Rev Baiana Saúde Pública. 2009;33(3):488-9.

7. Santos AM, Assis MMA, Rodrigues AAAO, Nascimento MAA, Jorge MSB. Linhas de tensões no processo de acolhimento das equipes de saúde bucal do Programa Saúde da Família: o caso de Alagoinhas, Bahia, Brasil. Cad Saúde Pública. 2007;23(1):75-85. autonomy of each subject about their citizenship and right to health.

Another important aspect revealed by the study concerns the actions taken by professionals of the FHS and the CAPS, with emphasis on the matricial mental health, home visits, the organization and conduction of group therapy, individual sessions, aiming for continuity of care. These represent a multidisciplinary and interdisciplinary work perspective, pooling knowledge and practices that favor an expanded perspective on the users' needs in their family, social and therapeutic context.

Finally, we highlight the importance of matricial support not just as training or a tool for the coordination of services. Furthermore, it proved to be a potent mechanism for the production of comprehensive care in its assistance function. Through the matricial support in mental health, it is possible to assume the completeness of health care as a principle guiding individual and collective practices. Also as guidance for the promotion of citizenship because it ensures that service users are cared for in their biopsychosocial needs in the context of primary health care.

8. Conejo SH, Colvero LA. O cuidado à família de portadores de transtorno mental. Rev Min Enferm. 2005;9(3):206-11.

9. Camargo BV. Alceste: um programa informático de análise quantitativa de dados textuais. In: Moreira ASP, Jesuíno JC, Camargo BV. Perspectivas teórico-metodológicas em representações sociais. João Pessoa: Ed. UFPB; 2005. p. 511-39.

10. Reinert M. Alceste: une metodologie d'analyse des domaim textuelles et une aplication. Bull Methodol Sociol. 1990;28(1):24-54.

11. Alba M. El método Alceste y su aplicación al estudio de las representaciones sociales del espacio urbano: el caso de la ciudad de México. Papers Social Represent. 2004;13(1):1-20.

12. Amarante P. Saúde mental e atenção psicossocial. 4ạ ed. Rio de Janeiro: FIOCRUZ; 2013.

13. Dimenstein $M$, Severo AK, Brito M, Pimenta AL, Medeiros V, Bezerra E. O apoio matricial em Unidades de Saúde da Família: experimentando inovações em saúde mental. Saúde Soc. 2009;18(1):63-74.

14. Barros S, Salles M. Mental health care management in the Brazilian National Health System. Rev Esc Enferm USP [Internet]. 2011 [cited 2013 Oct 27];45(n.esp2):1780-5. Available from: http://www.scielo.br/pdf/reeusp/v45nspe2/en_25.pdf

15. Filippon J, Kantorski LP. Humanização e loucura, em busca do humano que dialoga saúde. Physis Rev Saúde Coletiva. 2012;22(2):659-80.
Solvability of mental health care in the family health strategy: social representation of professionals and users Jorge MSB, Vasconcelos MGF, Junior EFC, Barreto LA, Rosa LRS, Lima LL 
16. Delfini PSS, Reis AOA. Articulação entre serviços públicos de saúde nos cuidados voltados à saúde mental infantojuvenil. Cad Saúde Pública. 2012;28(2):357-66.

17. Ribeiro JM, Inglez-Dias A. Políticas e inovação em atenção à saúde mental: limites ao descolamento do desempenho do SUS. Ciênc Saúde Coletiva. 2011;16(12):4623-33.

18. Silva LR, Beck CLC, Gobatto M, Dissen CM, Silva RM, Freitas NQ. Desafios na construção de uma rede de atenção em saúde mental. Cogitare Enferm. 2012;17(4):649-54.

19. Jorge MSB, Campos RO, Pinto AGA, Vasconcelos MGF, Cavalcante $\mathrm{CM}$, Flores $\mathrm{AZT}$, et al. Experiências com a gestão autônoma da medicação: narrativa de usuários de saúde mental no encontro dos grupos focais em Centros de Atenção Psicossocial. Physis Rev Saúde Coletiva. 2012;22(4):154
20. Pinto DM, Jorge MSB, Pinto AGA, Vasconcelos MGF, Cavalcante CM, Flores AZT, et al. Projeto Terapêutico Singular na produção do cuidado integral: uma construção coletiva. Texto Contexto Enferm. 2011;20(3):293-3

21. Quinderé PHD, Jorge MSB, Nogueira MSL, Costa LFA, Vasconcelos MGF. Acessibilidade e resolubilidade da assistência em saúde mental: a experiência do apoio matricial. Ciênc Saúde Coletiva. 2013;18(7):2157-66.

22. Albuquerque $A B B$, Bosi MLM. Visita domiciliar no âmbito da Estratégia Saúde da Família: percepções de usuários no Município de Fortaleza, Ceará, Brasil. Cad Saúde Pública. 2009;25(5):1103-12.

23. Catty J, Burns T, Knapp M, Watt H, Wright C, Henderson J, et al. Home treatment for mental health problems: a systematic review. Psychol Med. 2002;32(3):383-401

\section{Financial support}

Conselho Nacional de Desenvolvimento Científico e Tecnológico (CNPq). 